\title{
PERKEMBANGAN INTERMEDIASI BPR DI WILAYAH EKS KARESIDENAN BANYUMAS DAN FAKTOR-FAKTOR YANG MEMENGARUHINYA PERIODE TAHUN 2005-2011
}

\author{
Sheila Ardilla Yughi' ${ }^{1)}$, Rosyeilla Fat'ha Dewi, Supadi \\ ${ }^{1)}$ Dosen Fakultas Ekonomi Universitas Pamulang \\ dosen01719@unpam.ac.id
}

\begin{abstract}
ABSTRAK
Penelitian ini berjudul "Perkembangan Intermediasi BPR di Wilayah EksKaresidenan Banyumas dan Faktor-Faktor yang Memengaruhinya Periode Tahun 2005-2011". Tujuan dari penelitian ini adalah untuk mengetahui perkembanganan Loan to Deposit Ratio (LDR) pada Bank Perkreditan Rakyat (BPR) di wilayah Eks-Karesidenan Banyumas yang menunjukkan fungsi intermediasi BPR di wilayah Eks-Karesidenan Banyumas, untuk mengetahui pengaruh variabel BI rate, deposito, Produk Domestik Regional Bruto (PDRB), dan Non Performing Loan (NPL) baik secara bersama-sama maupun secara parsial terhadap intermediasi Bank Perkreditan Rakyat (BPR) di wilayah Eks-Karesidean Banyumas, dan untuk mengetahui variabel manakah yang paling berpengaruh besar terhadap intermediasi Bank Perkreditan Rakyat (BPR) di wilayah EksKaresidenan Banyumas.

Metode penelitian yang digunakan adalah metode analisis kuantitatif menggunakan analisis trend dan analisis regresi non linier berganda data panel. Data yang digunakan merupakan data panel yaitu gabungan dari data time series dan data cross section, dan data yang digunakan merupakan data tahunan dari tahun 2005 sampai dengan tahun 2011 sehingga jumlah data sebanyak 28 pengamatan.

Berdasarkan hasil uji regresi analisis data trend, perkembangan intermediasi yang dilihat dari besaran Loan to Deposit Ratio (LDR) menunjukkan perkembangan yang terus meningkat setiap tahunnya dan besaran LDR tersebut rata-rata sebesar 122 persen setiap tahunnya. Sedangkan berdasarkan hasil uji regresi linier berganda pada variabel dependen Loan to Deposit Ratio (LDR) BPR di wilayah Eks-Karesidenan Banyumas dapat diketahui variabel BI rate, deposito, Produk Domestik Regional Bruto (PDRB), dan Non Performing Loan (NPL) secara bersama-sama berpengaruh signifikan terhadap intermediasi BPR di wilayah Eks-Karesidenan Banyumas. Namun, secara parsial hanya variabel PDRB bernilai positif dan signifikan terhadap intermediasi BPR di wilayah EksKaresidenan Banyumas,dan variabel deposito berpengaruhsignifikan, namun bernilai negatif terhadap intermediasi BPR di wilayah Eks-Karesidenan Banyumas.
\end{abstract}

Kata Kunci: Intermediasi, BPR, Eks-Karesidenan Banyumas. 


\section{PENDAHULUAN}

\section{A. Latar Belakang}

Bank sebagai lembaga keuangan mempunyai fungsi intermediasi yaitu menghimpun dana dari masyarakat yang kelebihan dana dan menyalurkan dana yang dihimpunnya kepada masyarakat yang kekurangan dana (Abdullah, 2005:17). Seperti yang tercantum dalam Undang-Undang Nomor 10 tahun 1998 tentang perbankan dikatakan bahwa,

" bank adalah badan usaha yang menghimpun dana dari masyarakat dalam bentuk simpanan dan menyalurkannya kepada masyarakat dalam bentuk kredit dan atau bentuk-bentuk lainnya, dalam rangka meningkatkan taraf hidup masyarakat banyak".

Dalam Undang-Undang Nomor 10 tahun 1998 tentang perbankan, disebutkan juga bahwa ada dua jenis bank, yaitu Bank Umum dan Bank Perkreditan Rakyat (BPR). Bank Perkreditan Rakyat ( BPR ) merupakan salah satu jenis bank yang dikenal melayani golongan pengusaha mikro, kecil dan menengah. Dengan lokasi yang pada umumnya dekat dengan tempat masyarakat yang membutuhkan.

Sebagai lembaga intermediasi, kelangsungan usaha bank perkreditan rakyat (BPR) sangat ditopang oleh dana yang dihimpun dari masyarakat atau sering disebut dana pihak ketiga (DPK). Dana tersebut di bank perkreditan rakyat (BPR) terdiri dari deposito dan tabungan. Kemudian dana tersebut disalurkan kembali ke masyarakat dalam bentuk pinjaman atau lebih dikenal dengan istilah kredit atau loan (Sudarman, 2009: 3)

Peran bank dalam aktivitas menerima simpanan masyarakat dan menyalurkan dana kemasyarakat bisa dilihat dari besarnya loan deposit ratio (LDR), dimana rumus LDR adalah perbandingan antara kredit dengan simpanan (Manurung, dan Pratama, 2004: 150).

Menurut Mulyono (1995: 101), sebagian praktisi perbankan menyepakati bahwa batas aman dari LDR suatu bank adalah sekitar 85 persen. Namun batas toleransi berkisar antara 85 persen sampai dengan 100 persen.

Sepanjang tahun 2005 sampai dengan 2011, rasio LDR pada BPR di EksKaresidenan Banyumas terus mengalami peningkatan, besarnya rasio LDR tersebut mencapai 80 persen, sedangkan jumlah DPK yang terhimpun sebesar Rp. 6.422,30 juta, kredit yang diberikan kepada masyarakat sebesar Rp. 7.973,15 juta. Hal tersebut dapat dilihat dari tabel di bawah ini yang menunjukkan perkembangan indikator BPR yang menunjukkan fungsi intermediasi BPR pada tahun 2005 sampai dengan tahun 2011.

Tabel 1. Perkembangan Indikator BPR di Eks-Karesidenan Banyumas Tahun 2005-2011. 


\begin{tabular}{|c|c|c|c|c|c|c|c|}
\hline \multirow[t]{2}{*}{ Indikator } & \multicolumn{7}{|c|}{ Tahun } \\
\hline & 2005 & 2006 & 2007 & 2008 & 2009 & 2010 & 2011 \\
\hline \multicolumn{8}{|c|}{ Kredit (jutaan rupiah) } \\
\hline Banjarnegara & 177,31 & 187,06 & 285,46 & 345,68 & 430,89 & 523,77 & 565,69 \\
\hline Banyumas & 128,15 & 156,66 & 210,46 & 284,95 & 337,49 & 413,11 & 472,22 \\
\hline Cilacap & 140,97 & 168,32 & 237,42 & 309,43 & 349,44 & 383,62 & 456,28 \\
\hline Purabalingga & 85,81 & 111,85 & 158,31 & 177,72 & 237,96 & 281,94 & 355,16 \\
\hline $\mathrm{Jml}$ & 532,24 & 623,90 & 891,65 & $.117,79$ & $1.355,78$ & $1.602,44$ & $1.849,35$ \\
\hline \multicolumn{8}{|c|}{ DPK (jutaan rupiah) } \\
\hline Banjarnegara & 132,62 & 144,07 & 192,72 & 232,90 & 271,09 & 351,03 & 394,57 \\
\hline Banyumas & 118,42 & 155,73 & 198,21 & 240,15 & 310,15 & 361,57 & 472,66 \\
\hline Cilacap & 110,47 & 130,57 & 189,07 & 246,58 & 255,36 & 288,39 & 354,81 \\
\hline Purbalingga & 87,71 & 144,83 & 146,13 & 173,75 & 210,67 & 233,95 & 299,14 \\
\hline $\mathrm{Jml}$ & 449,22 & 545,20 & 726,13 & 893,38 & 1047,27 & 1234,94 & 1521,18 \\
\hline \multicolumn{8}{|l|}{ LDR (\%) } \\
\hline Banjarnegara & 133,70 & 129,84 & 148,12 & 148,43 & 158,94 & 149,21 & 143,37 \\
\hline Banyumas & 108,21 & 100,60 & 106,18 & 118,66 & 108,82 & 114,25 & 99,91 \\
\hline Cilacap & 127,61 & 128,91 & 125,57 & 125,49 & 136,84 & 133,22 & 128,60 \\
\hline Purbalingga & 97,83 & 97,40 & 108,33 & 102,29 & 112,95 & 120,51 & 121,57 \\
\hline
\end{tabular}

Sumber : Bank Indonesia Purwokerto 2005-2011.

Berdasarkan Tabel 1, dapat dilihat dari tahun 2005 sampai dengan tahun 2011 rasio LDR mengalami peningkatan di masing-masing BPR di wilayah EksKaresidenan Banyumas. Secara umum tingkat LDR pada BPR di EksKaresidenan Banyumas pada tahun 2005 sampai dengan 2011 terus mengalami peningkatan yang artinya kondisi tersebut tidak baik bagi BPR. Sesuai ketetapan yang ditentukan oleh Bank Indonesia batas aman rasio LDR perbankan antara 80 sampai dengan 110 persen, oleh karena itu penulis tertarik untuk meneliti faktor apa saja yang berpengaruh terhadap tingkat LDR pada BPR di Eks-karesidenan Banyumas.

\section{B. Perumusan Masalah} adalah:

Berdasarkan uraian di atas maka perumusan masalah dalam penelitian ini

1. Bagaimana perkembangan Loan to Deposit Ratio (LDR) Bank Perkreditan Rakyat (BPR) di wilayah Eks-Karesidenan Banyumas pada periode 2005 sampai dengan 2011 ?

2. Bagaimana pengaruh variabel $B I$ rate, jumlah deposito, Produk Domestik Regional Bruto (PDRB), Non Performing Loan (NPL) terhadap LDR BPR di wilayah Eks-Karasidenan Banyumas pada periode 2005 sampai dengan 2011 ?

\section{Pembatasan Masalah}

Penelitian ini untuk meneliti perkembangan dan faktor-faktor yang memengaruhi intermediasi BPR di Eks-Karesidenan Banyumas periode tahun 2005 sampai dengan tahun 2011 yang dapat dilihat dari rasio LDR. Untuk mengetahui hal tersebut digunakan variabel $B I$ rate, jumlah deposito, Produk Domestik Regional Bruto (PDRB), Non Performing Loan (NPL). 


\section{Tujuan Penelitian}

1. Untuk mengetahui perkembangan Loan to Deposit Ratio (LDR) yang menunjukkan fungsi intermediasi BPR di Eks-Karesidenan Banyumas periode tahun 2005 sampai dengan tahun 2011.

2. Untuk menganalisis pengaruh variabel BI rate, jumlah deposito, Produk Domestik Bruto (PDRB) per kapita, dan Non Performing Loan (NPL) baik secara simultan maupun parsial berpengaruh signifikan terhadap intermediasi BPR di Eks-Karesidenan Banyumas selama periode tahun 2005 sampai tahun 2011.

\section{E. Manfaat Penelitian}

1. Sebagai sumbangsih terhadap perkembangan ilmu pengetahuan khususnya ilmu ekonomi dalam bank dan lembaga perbankan.

2. Bagi akademisi dan para pembaca, penelitian ini dapat menambah wawasan dan dapat digunakan sebagai bahan informasi, referensi serta pertimbangan dalam penelitian selanjutnya.

3. Bagi dunia perbankan, sebagai kumpulan kajian untuk memperluas wawasan, serta dapat menjadi sumbangan pemikiran dalam mengembangkan fungsi intermediasinya.

\section{TINJAUAN PUSTAKA}

\section{A. Intermediasi Bank}

Bank merupakan lembaga intermediasi keuangan yang mempunyai fungsi untuk mengalihkan dana dari unit ekonomi surplus ke unit ekonomi defisit. Bank sebagai lembaga intermediasi pada prinsipnya merupakan unit usaha yang dikelola dan dioperasikan untuk mencapai tujuan tertentu. Fungsi intermediasi bank melekat dan sesuai dengan karakteristik usaha bank, sebagai lembaga penyedia jasa keuangan, penghimpun dan penyalur dana dengan berlandaskan kepercayaan yang diberikan oleh para nasabahnya. Bank sebagai lembaga intermediasi anatar pihak-pihak yang membutuhkan dana, maka diperlukan bank yang mempunyai kinerja yang sehat. Fungsi intermediasi bank pada dasarnya terdiri dari dua aktivitas yaitu, pertama aktivitas peningkatan penyerapan dana pihak ketiga, diantaranya melalui produk giro, tabungan dan deposito atau produk bank lainnya, kedua adalah aktivitas peningkatan penyaluran dana ke dalam bentuk aktiva produk kredit.

\section{B. Loan to Deposit Ratio (LDR)}

Loan to Deposit ratio (LDR) adalah rasio antara loan atau kredit (fungsi penyaluran dana) dengan deposit atau dana yang masuk (fungsi penghimpunan dana) ke bank umum (DPK). Loan to Deposit Ratio (LDR) menyatakan berapa jauh kemampuan bank dalam membayar kembali penarikan dana yang dilakukan peminjaman dengan mengandalkan kredit yang diberikan sebagai sumber likuiditasnya.

\section{BI Rate}

BI rate adalah suku bunga kebijakan yang mencerminkan sikap atau stance kebijakan moneter yang ditetapkan oleh bank Indonesia dan diumumkan kepada publik. BI rate diumumkan oleh Dewan Gubernur Bank Indonesia setiap Rapat Dewan Gubernur bulanan dan diimplementasikan pada operasi moneter yang 
dilakukan Bank Indonesia melalui pengelolaan likuiditas (liquidity management) di pasar uang untuk mencapai sasaran operasional kebijakan moneter.

\section{Simpanan Deposito}

Simpanan deposito merupakan simpanan jenis ketiga yang dikeluarkan oleh bank. Menurut Undang-Undang No. 10/1998, Pasal 1 ayat 7 (1998), deposito adalah simpanan yang penarikannya hanya dapat dilakukan pada waktu tertentu berdasarkan perjanjian nasabah penyimpan dengan bank.

\section{E. Dana Pihak Ketiga (DPK)}

Dana pihak ketiga (simpanan) yang dijelaskan dalam Undang-Undang Perbankan RI Nomor 10 tahun 1998 tentang perbankan adalah dana yang dipercayakan oleh masyarakat kepada bank berdasarkan perjanjian penyimpanan dana dalam bentuk giro, deposito, sertifikat deposito, tabungan, dan atau bentuk lainnya yang dipersamakan dengan itu.

\section{F. Kredit}

Menurut Undang-Undang Nomor 7 tahun 1992 tentang perbankan sebagaimana telah diubah dengan Undang-Undang Nomor 10 tahun 1998, yang mengatakan bahwa. "kredit adalah penyediaan uang atau tagihan yang dapat dipersamakan dengan itu berdasarkan persetujuan atau kesepakatan pinjammeminjam antara bank dengan pihak lain yang mewajibkan pihak peminjam untuk melunasi hutangnya setelah jangka waktu tertentu dengan jumlah bunga".

\section{G. Non Performing Loan (NPL)}

Menurut Kamus Bank Indonesia, Non Performing Financing (NPF) atau Non Performing Loan (NPL) adalah kredit bermasalah yang terdiri dari kredit yang berklasifikasi kurang lancar, diragukan dan macet. Termin NPL diperuntukkan bagi bank umum, sedangkan NPF untuk bank syariah. Oleh kebanyakan bank sentral, kredit bermasalah dikategorikan sebagai aktiva produktif bank yang diragukan kolektabilitasnya. Untuk menjaga keamanan dana para deposan, bank sentral mewajibkan bank umum menyediakan cadangan penghapusan kredit bermasalah. Dengan demikian, semakin besar jumlah saldo kredit bermasalah yang dimiliki bank, akan semakin besar jumlah dana cadangan yang harus segera disediakan, serta semakin besar pula biaya yang harus mereka tanggung untuk mengadakan dana cadangan tersebut. Hal ini mempengaruhi profitabilitas usaha bank yang bersangkutan.

\section{H. Produk Domestik Regional Bruto (PDRB)}

Produk Domestik Regional Bruto (PDRB) merupakan salah satu indikator pertumbuhan ekonomi suatu negara atau wilayah atau daerah. Pertumbuhan tersebut dapat dipengaruhi oleh beberapa faktor, diantaranya infrastruktur ekonomi. Dengan demikian, PDRB merupakan indikator untuk mengatur sampai sejauhmana keberhasilan pemerintah dalam memanfaatkan sumber daya yang ada, dan dapat digunakan sebagai perencanaan dan pengambilan keputusan.

\section{Kerangka Pemikiran}

Fungsi perbankan sebagai lembaga intermediasi adalah fungsi untuk menghimpun dana dari masyarakat yang kelebihan dana dan menyalurkan dana yang dihimpunnya kepada masyarakat yang kekurangan dana. Dana Pihak ketiga (DPK) yang dapat dihimpun oleh bank mengawali kegiatan bank dalam melaksanakan fungsinya sebagai lembaga intermediasi, yang kemudian dana 
tersebut akan disalurkan kembali kepada masyarakat dalam bentuk kredit. Besar kecilnya DPK yang dapat dihimpun oleh bank akan mempengaruhi tingkat kredit yang dapat dikukurkan oleh perbankan.

Jumlah deposito dimasukkan kedalam variabel yang mempengaruhi besar kecilnya DPK yang terhimpun, karena DPK pada BPR terdiri dari tabungan dan deposito. Jumlah deposito mempunyai pengaruh yang negatif terhadap fungsi intermediasi. Semakin meningkat jumlah deposito maka semakin tinggi pula tingkat kredit yang disalurkan kepada masyarakat daerah, namun jumlah deposito tidak memiliki hubungan searah dengan Loan to Deposit Ratio (LDR), karena nilai Loan to Deposit Ratio merupakan hasil dari kredit dibagi dengan deposito. Hal ini berarti semakin besar jumlah deposito yang terhimpun, makan akan menurunkan besaran Loan to Deposit Ratio (LDR). Kemudian variabel BI Rate dan Produk Domestik Regional Bruto mempengaruhi tingkat intermediasi BPR dari sisi makro ekonomi.

Suku bunga Bank Indonesia atau BI Rate merupakan sebagai acuan bank-bank dalam menentukan tingkat suku bunga perbankan yang dalam hal ini adalah BPR. Suku bunga Bank Indonesia atau BI Rate mempunyai hubungan yang negatif dengan fungsi bank sebagai lembaga intermediasi. Menurut penelitian yang dilakukan oleh Purwaningtyas pada tahun 2011, semakin tinggi tingkat suku bunga yang di tetapkan bank sentral, dalam hal ini yaitu BI Rate juga akan meningkatkan proporsi Dana Pihak Ketiga (DPK) yang disimpan oleh masyarakat di bank dalam bentuk tabungan, yang kemudian akan menjadikan semakin kecil Loan to Deposit Ratio (LDR) perbankan. Hal ini berhubungan dengan harapan masyarakat dalam mendapat balas jasa dari bank melalui tingkat suku bunga ini.

Produk Domestik Regional Bruto (PDRB) yang meningkat mempunyai pengaruh yang positif terhadap fungsi intermediasi perbankan, karena dengan meningkatnya Produk Domestik Regional Bruto (PDRB) mencerminkan adanya peningkatan kemampuan ekonomi masyarakat, sehingga bagi perbankan ini merupakan indikator dalam keputusan memberikan kredit kepada masyarakat. Diharapkan Produk Domestik Regional Bruto (PDRB) yang meningkat merupakan pencerminan dari kondisi perekonomian masyarakat yang stabil dan positif sehingga pengembalian kredit masyarakat kepada perbankan juga dapat berlangsung dengan lancar, yang berarti semakin besar Produk Domestik Regional Bruto (PDRB) semakin besar pula Loan to Deposit Ratio (LDR) perbankan.

Non Performing Loan (NPL) dimasukkan kedalam variabel yang mempengaruhi LDR dari sisi penawaran kredit. Besar kecilnya NPL mempengaruhi proporsi kredit yang dikucurkan oleh perbankan yang dalam hal ini adalah BPR. Non Performing Loan (NPL) memiliki hubungan yang negatif dengan Loan to Deposit Ratio (LDR) BPR. Non Performing Loan (NPL) merupakan jumlah kredit macet dan kredit bermasalah yang diberikan oleh BPR kepada nasabah, salah satu indikator pertimbangan BPR dalam menyalurkan kreditnya kepada masyarakat, dimana semakin tinggi tingkat NPL maka akan semakin rendah tingkat penyaluran kredit BPR yang diberikan kepada masyarakat, sehingga NPL mempunyai hubungan yang negatif dengan Loan to Deposit Ratio (LDR) BPR. 
Dari uraian tersebut maka dapat digambarkan perumusan model penelitian sebagai berikut.

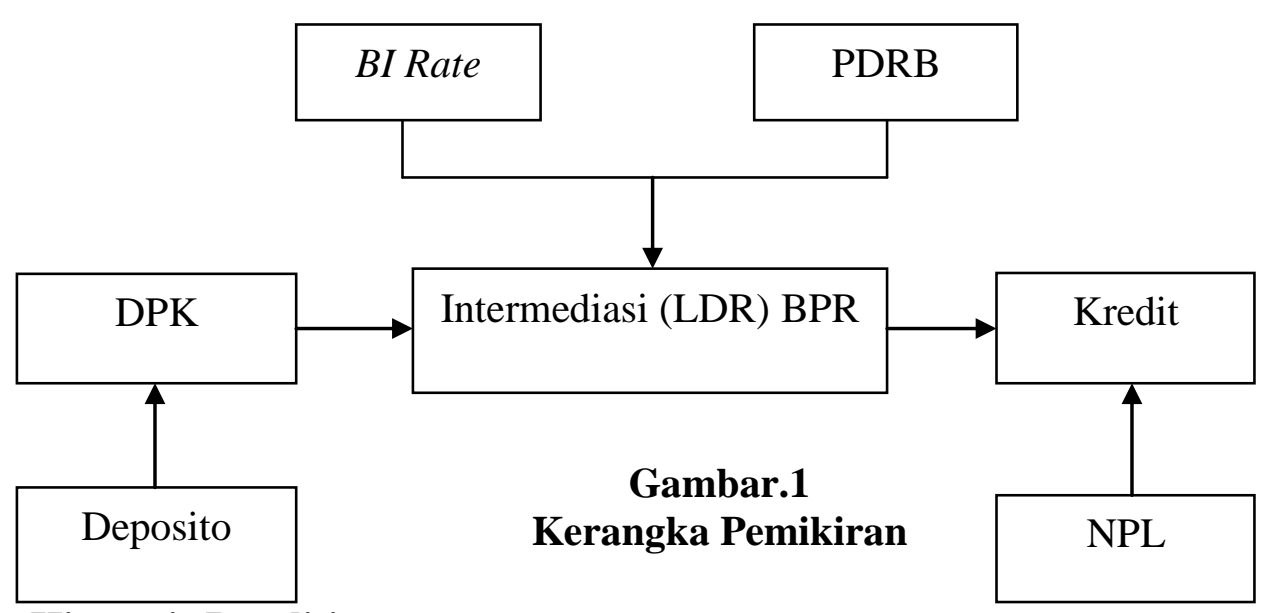

\section{J. Hipotesis Penelitian}

Berdasarkan kerangka pemikiran tersebut maka dalam penelitian ini diuji hipotesis sebagai berikut.

a. diduga Loan to Deposit Ratio (LDR) BPR di wilayah Eks-Karesidenan Banyumas periode tahun 2005 sampai dengan tahun 2011 menunjukkan trend yang meningkat;

b. masing-masing variabel secara bersama mempunyai pengaruh yang signifikan terhadap LDR pada BPR di Eks-karesidenan Banyumas periode tahun 2005 sampai dengan tahun 2011, namun secara parsial masing-masing varibel mempunyai pengaruh sebagai berikut.

1) diduga variabel BI rate berpengaruh negatif terhadap LDR dan tidak signifikan;

2) diduga jumlah simpanan deposito berpengaruh negatif terhadap LDR dan signifikan;

3) diduga Produk Domestik Regional Bruto (PDRB) berpengaruh positif terhadap LDR dan signifikan;

4) diduga Non Performing Loan (NPL) berpengaruh negatif terhadap LDR dan tidak signifikan.

\section{METODOLOGI PENELITIAN}

\section{A. Tempat dan Waktu Penelitian}

Penelitian ini dilakukan di Bank Indonesia Purwokerto. Penelitian ini dilaksanakan dalam kurun waktu 2 bulan, sejak bulan Mei - Juni 2014.

\section{B. Metode Penelitian}


Metode penelitian yang digunakan dalam penelitian ini adalah jenis penelitian deskriptif melalui studi pustaka (library research) dan didukung analisis data sekunder yang bersifat kuantitatif.

\section{Teknik Penentuan Data}

Untuk mencapai tujuan penelitian ini, maka diperlukan data-data yang relevan dengan masalah yang diteliti dengan mengumpulkan data-data sekunder. Sumber data dan informasi diperoleh dari :

a. Laporan Statistik dan Ekonomi Keuangan Daerah yang diterbitkan secara bulanan dan tahunan oleh Bank Indonesia Purwokerto.

b. Laporan bulanan BPR yang merupakan laporan keuangan BPR di wilayah Eks-Karesidenan Banyumas oleh Bank Indonesia Purwokerto.

c. Laporan mengenai besarnya PDRB di masing-masing wilayah di kawasan Eks-Karesidenan Banyumas oleh Badan Pusat Statistik Purwokerto.

\section{Metode Analisis Data}

1. Untuk mengetahui perkembangan fungsi intermediasi BPR di wilayah EksKaresidenan Banyumas, digunakan alat analisis Trend. Analisis trend merupakan suatu metode analisis statistika yang ditujukan untuk melakukan suatu estimasi atau peramalan pada masa yang akan datang. Untuk melakukan peramalan yang baik maka dibutuhkan berbagai macam informasi atau data yang cukup banyak dan diamati dalam periode waktu yang relatif cukup panjang.

Persamaan linier dari garis time series adalah sebagai berikut:

$\mathrm{Y}=\alpha+\beta \mathrm{X}$

Keterangan:

$\mathrm{Y}=$ LDR BPR di Eks-Karesidenan Banyumas

$\mathrm{X} \quad=$ Variabel waktu (biasanya dalam tahun).

$\alpha \quad=$ Konstanta

$\beta=$ Koefisien Regresi

Sedangkan untuk mencari nilai konstanta a dan b dapat dipakai persamaan sebagai berikut:

$\alpha=\frac{\sum \text { Y rata-rata }}{n}$

$\beta=\frac{\sum X Y}{X^{2}}$

2. Untuk mengetahui pengaruh variabel jumlah deposito, BI Rate, Produk Domestik Regional Bruto (PDRB), dan Non Performing Loan (NPL) trehadap intermediasi BPR di Eks-Karesidenan Banyumas periode 2005 sampai dengan 2012 digunakan alat analisis regresi linier berganda data panel. Penelitian ini menggunakan model regresi data panel karena data-data yang akan diolah merupakan data cross seections observations dan poolong of time series yang diperoleh dan diteliti sejalan dengan perjalanan waktu. Penelitian ini menggunakan satu variabel independen yang memiliki satuan yang berbeda yaitu PDRB. Oleh karena itu, hanya variabel tersebut yang disamakan satuannya dalam bentuk logaritma natural (ln), sehingga secara 
matematis model persamaan regresi non linier data panel dapat ditulis sebagai berikut:

$\mathrm{Y}_{\mathrm{i}, \mathrm{t}}=\alpha+\beta_{1} X_{1 i t}+\beta_{2} X_{2 i t}+\beta_{3} \operatorname{Ln} X_{3 \mathrm{it}}+\beta_{4} X_{4 \mathrm{it}}+\varepsilon_{\mathrm{it} .}$

Keterangan :

LDR

$\beta_{0} \quad=$ Konstanta

= Loan to Deposite Ratio

$\beta_{1} \beta_{2} \beta_{3} \beta_{4} \quad=$ Koefisien (parameter) struktural

$\mathrm{X}_{1} \quad=$ BI Rate atau suku bunga Bank Indonesia

$\mathrm{X}_{2} \quad=$ Jumlah Simpanan Deposito yang satuannyadisamakan

$\mathrm{LnX}_{3}$ dalam bentuk logaritma = Produk Domestik Regional Bruto yang satuannya disamakan dalam bentuk logaritma

$\mathrm{X}_{4} \quad=$ Non Performing Loan (NPL)

$\varepsilon_{\text {it }} \quad=$ Variabel Penggangu

Dalam pemodelan data Panel terdapat tiga estimasi perameter model, yaitu Ordinary Least Square (OLS), Model Efek Tetap (MET), Model Efek Random (MER). (Nachrowi, dan Usman, 2006: 3011). Dalam menentukan teknik mana yang paling tepat, maka harus dilakukan pengujian. Pertama, uji statistik $\mathrm{F}$ digunakan untuk memilih antara metode OLS tanpa variabel dummy atau Fixed Effect. Kedua, uji Langrange Multiplier (LM) digunakan untuk memilih antara OLS tanpa variabel dummy atau Random Effect. Terakhir, untuk memilih Fixed Effect atau Random Effect digunakan uji yang dikemukakan Hausman. (Nachrowi, dan Usman, 2006: 330)

3. Pengujian Model secara Statistik

a. Uji Kecocokan (Goodness of Fit)

Penelitian ini termasuk analisis regresi majemuk, sehingga digunakan pengujian terhadap nilai koefisien determinasi yang disesuaikan (adjusted $R$ squared). Nilai adjusted $R$-squared $\left(\mathrm{R}^{2}\right)$ mencerminkan seberapa besar variasi dari variabel terikat yang dapat dijelaskan oleh variabel bebas dalam suatu persamaan struktural. Jika nilai adjusted $R$-squared $\left(\mathrm{R}^{2}\right)$ semakin mendekati 1 maka garis regresi yang dicocokan akan semakin dapat menjelaskan variasi dalam Y (variabel terikat).

b. $U j i-F$ (Uji Fisher)

Uji ini digunakan untuk menguji kelayakan model (goodness of fit). Hipotesis ini dirumuskan sebagai berikut :

$$
\mathrm{H} 1: \mathrm{b} 1, \mathrm{~b} 2, \mathrm{~b} 3, \mathrm{~b} 4 \geq 0
$$

artinya Jika tingkat signifikansi lebih kecil dari 0,05 atau 5\% maka model yang digunakan dalam kerangka pikir teoritis layak untuk digunakan, sementara jika tingkat signifikansi lebih besar dari 0,05 atau 5\% maka model yang digunakan dalam kerangka pikir teoritis tidak layak untuk digunakan.

c. Uji Keberartian Koefisien (bi) dilakukan dengan statistik - t. Hal ini digunakan untuk menguji koefisien regresi secara parsial dari variabel independennya. Adapun hipotesis dirumuskan sebagai berikut:

$$
\mathrm{H} 1: \mathrm{bi} \geq 0
$$

artinya jika tingkat signifikansi lebih kecil dari 0,05 atau 5 persen maka hipotesis yang diajukan diterima atau dikatakan signifikan, artinya secara 
parsial variable bebas (X1 s/d X4) berpengaruh signifikan terhadap variabel dependen $(\mathrm{Y})=$ hipotesis diterima, sementara jika tingkat signifikansi lebih besar dari 0,05 atau 5 persen maka hipotesis yang diajukan ditolak atau dikatakan tidak signifikan, artinya secara parsial variabel bebas (X1 s/d X4) tidak berpengaruh signifikan terhadap variabel dependen (Y), hipotesis ditolak.

\section{HASIL DAN PEMBAHASAN}

\section{Perekembangan Intermediasi BPR di wilayah Eks-Karesidenan Banyumas periode 2005-2011.}

Perkembangan besaran Loan to Deposite Ratio (LDR) ini menunjukkan bagaimana perkembangan proporsi kredit yang diberikan dengan Dana Pihak Ketiga (DPK) yang berhasil dihimpun oleh BPR. Selama periode penelitian, DPK mengalami presentase yang terus menibngkat. Dana Pihak Ketiga (DPK) yang meningkat ini meningkatkan kemampuan BPR dalam menyalurkan dana kepada masyarakat dalam bentuk kredit. Dapat dibuktikan dengan meningkatnya jumlah kredit yang disalurkan oleh bank seiring dengan peningkatan DPK.

Hasil analisis trend untuk melihat perkembangan besarana LDR dan meramalkan besaran LDR beberapa tahun kedepan dapat dilihat pada Tabel 2 .

Tabel 2. Hasil Perhitungan Rasio LDR dengan Analisis Trend

\begin{tabular}{r|r|r|r|r}
\hline \multicolumn{1}{c|}{ Tahun } & $\mathrm{X}$ & Y rata-rata & \multicolumn{1}{c}{$\mathrm{X}^{2}$} & \multicolumn{1}{c}{ X.Y } \\
\hline 2005 & -3 & 116,84 & 9 & $-350,52$ \\
2006 & -2 & 114,19 & 4 & $-228,38$ \\
2007 & -1 & 121,80 & 1 & $-121,80$ \\
2008 & 0 & 123,72 & 0 & 0 \\
2009 & 1 & 129,39 & 1 & 129,39 \\
2010 & 2 & 129,25 & 4 & 258,50 \\
2011 & 3 & 122,65 & 9 & 367,95 \\
\hline Jumlah & 0 & 857,84 & 28 & 55,14 \\
\hline
\end{tabular}

Sumber : Bank Indonesia Purwokerto

Untuk mencari nilai $\alpha$ dan $\beta$ adalah sebagai berikut:

$\alpha=\frac{\sum \mathrm{Y} \text { rata }- \text { rata }}{n}=\frac{857,84}{7}=122,55$

$\beta=\frac{\sum \mathrm{XY}}{\mathrm{X}^{2}} \quad=\frac{55,14}{28}=1,97$

Maka persamaan garis liniernya adalah sebagai berikut :

$Y=122,55+1,97 X$

Dengan menggunakan persamaan tersebut, dapat diramalkan rasio LDR pada tahun 2020 adalah :

$Y=122,55+1,97 X$ (untuk tahun 2020 nilai $X$ adalah 12), sehingga.

$Y=122,55+23,64=146,19$, artinya rasio LDR pada tahun 2020 di perkirakan sebesar 146,19 persen.

2. Pengaruh Variabel BI Rate, Deposito, Produk Domestik Regional Bruto (PDRB), dan Non Performing Loan (NPL) terhadap Intermediasi Bank 


\section{Perkreditan Rakyat (BPR) di Eks-Karesidenan Banyumas Periode 2005- 2011.}

Variabel dependen dalam analisis regresi ini yaitu besaran LDR BPR di wilayah Eks-Karesidenan Banyumas, sedangkan variabel independennya adalah $\mathrm{BI}$ rate, deposito, PDRB, dan NPL. Untuk mengetahui hasil analisis tentang pengaruh variabel BI rate, deposito, PDRB, dan NPL terhadap rasio LDR di BPR wilayah Eks-Karesidenan Banyumas dilakukan melalui analisis regresi linier berganda dengan menggunakan data panel. berikut hasil perhitungannya.

Tabel 3. Hasil Estimasi Regresi Non Linier Berganda

\begin{tabular}{lrrrr}
\hline Variabel & Koefisien & \multicolumn{1}{l}{ Std.Error } & t-Statistik & Probabilitas \\
\hline Konstanta & $-1926,56$ & 393,17 & $-4,90$ & 0,00 \\
BI Rate & $-0,19$ & 0,74 & $-0,26$ & 0,80 \\
Deposito & $-0,25$ & 0,04 & $-6,29$ & 0,00 \\
PDRB & 137,56 & 25,81 & 5,33 & 0,00 \\
NPL & $-0,32$ & 0,45 & $-0,71$ & 0,49 \\
\hline Fixed Effect (cross) & & & & \\
Banjarnegara & 77,13 & & & \\
Banyumas & $-24,26$ & & & \\
Cilacap & $-103,59$ & & & \\
Purbalingga & 50,72 & \multicolumn{5}{c}{ Adjusted $R$-Square 0,909333}
\end{tabular}

Sumber : Eviews 6

Dari persamaan berdasarkan Tabel di atas dapat dibuat persamaan regresi non linier berganda di masing-masing kabupaten sebagai berikut:

a. LDR Kabupaten Banjarnegara :

$$
Y=-1.849,43-0,19 X_{1}-0,25 X_{2}+137,56 \ln X_{3}-0,32 X_{4}
$$

b. LDR Kabupaten Banyumas :

$$
Y=-1.950,82-0,19 X_{1}-0,25 X_{2}+137,56 \ln X_{3}-0,32 X_{4}
$$

c. LDR Kabupaten Cilacap :

$$
Y=-2.030,15-0,19 X_{1}-0,25 X_{2}+137,56 \ln X_{3}-0,32 X_{4}
$$

d. LDR Kabupaten Purbalingga :

$Y=1.875,84-0,19 X_{1}-0,25 X_{2}+137,56 \ln X_{3}-0,32 X_{4}$

Berdasarkan hasil regresi diatas diperoleh nilai konstanta masing-masing kabupaten yang dapat digunakan untuk menjelaskan kabupaten yang memiliki pengaruh terbesar terhadap Intermediasi BPR yang dilihat dari rasio LDR. Kabupaten Cilacap merupakan kabupaten yang memiliki pengaruh paling besar terhadap LDR, sedangkan kabupaten Banjarnegara merupakan kabupaten yang memiliki pengaruh terkecil terhadap LDR.

\section{Pengujian Model secara Statistik}

\section{a. Uji Kebaikan-Kesesuaian (goodness of fit)}

Nilai adjusted R-squared dari hasil estimasi pada tabel diperoleh sebesar 0,909333. Ini berarti bahwa 90,93 persen variasi perubahan bi rate, jumlah 
deposito, Produk Domestik Regional Bruto (PDRB), dan Non Performing Loan (NPL) mampu menjelaskan variasi perubahan intermediasi BPR, dan sisanya sebesar 9,07 persen dijelaskan oleh variasi perubahan variabel lain di luar model.

\section{b. Uji Pengaruh secara Bersama-sama (Uji F-statistik)}

Tabel 4. Hasil Uji F-statistik Intermediasi BPR di Eks-Karesidenan Banyumas periode 2005-2011.

\begin{tabular}{cc}
\hline \multirow{2}{*}{ F-statistik } & F-tabel $(d f 1=23, d f 2=5)$ \\
\cline { 2 - 2 } & 5 persen \\
\hline 39,6846 & 2,71 \\
\hline
\end{tabular}

Sumber : Eviews 6, data diolah

Dari hasil perhitungan data dengan tingkat keyakinan sebesar 95 persen $(\alpha=0,05)$ diperoleh nilai F-tabel sebesar 2,71. Dari hasil analisis data Fhitung yang diperoleh sebesar 39,6846, sehingga dengan demikian nilai Fhitung lebih besar dari nilai F-tabel $(39,6846>2,71)$ yang berarti bahwa variabel BI rate, jumlah deposito, Produk Domestik Regional Bruto (PDRB), dan Non Performing Loan (NPL) secara bersama-sama berpengaruh secara signifikan terhadap intermediasi BPR di Eks-Karesidenan Banyumas periode 2005 sampai dengan 2011.

c. Uji Pengaruh secara Parsial (Uji t-statistik)

Tabel 5. Hasil Uji-t Intermediasi BPR di Wilayah Eks-Karesidenan Banyumas periode 2005-2011.

\begin{tabular}{lrrr}
\hline \multicolumn{1}{c}{ Variabel } & Koefisien Regresi & \multicolumn{1}{c}{ t hitung } & \multicolumn{2}{c}{$\mathrm{t}$ tabel } \\
\hline BI rate & $-0,19$ & $-0,260197$ & $-1,714$ \\
Deposito & $-0,25$ & $-6,287923$ & $-1,714$ \\
PDRB & 137,56 & 5,328739 & 1,714 \\
NPL & $-0,32$ & $-0,708264$ & $-1,714$ \\
\hline
\end{tabular}

Sumber : Eviews 6, data diolah

Berdasarkan data pada Tabel dapat diketahui bahwa variabel deposito dan PDRB secara parsial berpengaruh signifikan terhadap LDR di BPR wilayah Eks-Karesidenan Banyumas karena t-hitung $>\mathrm{t}$ tabel dan berada di daerah penolakan Ho, yang artinya variabel tersebut secara parsial mempunyai pengaruh yang signifikan, berarti hipotesis yang menyatakan bahwa variabel deposito dan PDRB secara parsial berpengaruh signifikan terhadap LDR diterima.

Variabel BI rate dan NPL secara parsial tidak berpengaruh secara signifikan terhadap LDR di BPR wilayah Eks-Karesidenan Banyumas karena variabel BI rate dan NPL t-hitung < t-tabel dan berada pada daerah Ho diterima, yang artinya variabeltersebut secara parsial tidak mempunyai pengaruh yang signifikan. Hal ini berarti hipotesis yang menyatakan variabel BI rate dan NPL secara parsial tidak mempunyai pengaruh yang signifikan ditolak.

\section{1) Analisis Ekonomi}




\section{(a) BI Rate}

Berdasarkan hasil uji $\mathrm{t}$ nilai $\mathrm{t}$ hitung BI rate sebesar -0,260197, dengan menggunakan $\alpha=0,05$ di perolehnilai $t$ tabel sebesar $-1,714$. Berdasarkan hasil tersebut dapat dilihat bahwa nilai $\mathrm{t}$ hitung $>\mathrm{t}$ tabel, sehingga dapat disimpulkan bahwa variabel BI rate secara parsial tidak berpengaruh signifikan. Artinya peningkatan BI rate tidak berpengaruh terhadap peningkatan LDR di BPR wilayah Eks-Karesidenan Banyumas.

Pengaruh BI rate terhadap Loan to Deposit Ratio (LDR) BPR di wilayah Eks-Karesidenan Banyumas dalam penelitian ini berpengaruh negatif yaitu sebesar $-0,19$, artinya bahwa setiap kenaikan $B I$ rate 1 persen akan menurunkan tingkat Loan to Deposit Ratio (LDR) sebesar 0,19 persen.

BI rate merupakan sebagai acuan bagi perbankan untuk menetapkan tingkat suku bunga bank maupun kredit yang dalam penelitian ini adalah BPR, sehingga menjadi alasan bertambahnya penghimpunan Dana Pihak Ketiga (DPK) dari masyarakat daerah ke BPR. Namun berdasarkan kondisi yang ada, rata-rata perbankan umum maupun BPR ada yang tidak mematok suku bunga sesuai yg ditetapkan oleh Bank Indonesia, karena mereka mempunyai alasan masing-masing diantaranya mencari pendapatanan atau keuntungan yang lebih besar. Dana Pihak Ketiga (DPK) yang bertambah berarti menandakan bertambahnya jumlah kesediaan dana yang akan dikelola oleh BPR, salah satunya dalam fungsi bank sebagai lembaga intermediasi. Fungsi intermediasi menyalurkan Dana Pihak Ketiga (DPK) dalam bentuk kredit. Oleh karena itu meskipun terjadi penuruan BI rate besaran LDR tidak turun dan tetap naik

\section{(b) Deposito}

Berdasarkan hasil uji t nilai t hitung deposito sebesar -6,287923, dengan menggunakan $\alpha=0,05$ diperoleh nilai $t$ tabel sebesar $-1,714$. Berdasarkan hasil tersebut dapat dilihat bahwa nilai $\mathrm{t}$ hitung $<\mathrm{t}$ tabel, sehingga dapat disimpulkan bahwa variabel deposito secara parsial berpengaruh signifikan terhadap LDR.

Pengaruh deposit terhadap Loan to Deposit Ratio (LDR) BPR di wilayah Eks-Karesidenan Banyumas dalam penelitian ini berpengaruh negatif yaitu sebesar -0,25, artinya bahwa setiap kenaikan deposito 1 juta rupiah maka akan menurunkan tingkat Loan to Deposit Ratio (LDR) sebesar 0,25 persen.

Peningkatan jumlah deposito yang dapat dihimpun oleh perbankan yaitu BPR, mencerminkan adanya peningkatan kredit yang disalurkan, namun berdasarkan teori yang ada peningkatan deposito tidak berjalan searah dengan besaran Loan to Deposit Ratio (LDR) sehingga tingkat intermediasi BPR mengalami penurunan

\section{(c) Produk Domestik Regional Bruto (PDRB)}

Berdasarkan hasil uji t nilai t hitung PDRB sebesar 5,328739, dengan menggunakan $\alpha=0,05$ diperoleh nilai $\mathrm{t}$ tabel sebesar 1,714. Berdasarkan hasil tersebut dapat dilihat bahwa nilai t hitung $>\mathrm{t}$ tabel, 
sehingga dapat disimpulkan bahwa variabel PDRB secara parsial berpengaruh signifikan terhadap LDR.

Pengaruh PDRB terhadap LDR BPR di wilayah Eks-Karesidenan Banyumas dalam penelitian ini berpengaruh positif yaitu sebesar 137,56, artinya bahwa setiap kenaikan PDRB 1 persen akan menaikkan tingkat Loan to Deposit Ratio (LDR) sebesar 1,3756 persen.

Peningkatan Produk Domestik Regional Bruto (PDRB) mencerminkan adanya peningkatan kemampuan ekonomi daerah, hal ini merupakan indikator penting bagi perbankan yang dalam penelitian ini adalah BPR sebagai sinyal positif dalam memberikan kreditnya kepada masyarakat daerah, karena kondisi perekonomian masyarakat daerah yang stabil dan baik menjadikan proses pengembalian kredit akan berlangsung pula dengan lancar. Pertumbuhan Produk Domestik Regional Bruto (PDRB) ini menjadi acuan BPR sebagai indikator pertumbuhan perekonomian daerah yang baik pula. Jika penyaluran kredit oleh BPR baik maka akan semakin baik pula proporsi kredit yang diberikannya, yang berarti semakin bertambah juga besaran Loan to Deposit Ratio (LDR) BPR.

(d) Non Performing Loan

Berdasarkan hasil uji t nilai t hitung NPL sebesar -0,708264, dengan menggunakan $\alpha=0,05$ di perolehnilai t tabel sebesar $-1,714$. Berdasarkan hasil tersebut dapat dilihat bahwa nilai t hitung $>\mathrm{t}$ tabel, sehingga dapat disimpulkan bahwa variabel NPL secara parsial tidak berpengaruh signifikan. Artinya peningkatan NPL tidak berpengaruh terhadap peningkatan LDR di BPR wilayah Eks-Karesidenan Banyumas.

Pengaruh NPL terhadap Loan to Deposit Ratio (LDR) BPR di wilayah Eks-Karesidenan Banyumas dalam penelitian ini berpengaruh negatif yaitu sebesar - 0,32, artinya bahwa setiap kenaikan 1 persen NPL akan menurunkan tingkat Loan to Deposit Ratio (LDR) sebesar 0,32 persen.

Dalam penelitian ini pengaruh Non Performing Loan terhadap Loan to Deposit Ratio (LDR) pada akhirnya mencerminkan bagaimana pengaruh Non Performing Loan (NPL) terhadap intermediasi BPR, dimana NPL berpengaruh negatif dan tidak signifikan, hal ini dikarenakan perbankan dalam memberikan atau menyalurkan kredit kepada nasabah tidak bergantung pada tingkat NPL namun lebih bergantung pada jumlah dana yang berhasil dihimpun oleh bank. Nilai NPL yang rendah akan menunjukkan semakin membaiknya fungsi intermediasi pada BPR di wilayah Eks-Karesidenan Banyumas.

\section{KESIMPULAN DAN SARAN}

\section{A. Kesimpulan}

Berdasarkan hasil penelitian dan pembahasan maka dapat disimpulkan sebagai berikut:

1. Angka rata-rata Loan to Deposit Ratio (LDR) pada BPR di wilayah EksKaresidenan Banyumas mencapai 122,65 persen sampai akhir periode 
penelitian. Nilai LDR menunjukkan rasio yang melebihi batas aman yang telah ditetapkan oleh Bank Indonesia sebesar 80 sampai dengan 110 persen.

2. Variabel BI rate, jumlah deposito, Produk Domestik Regional Bruto (PDRB), dan Non Performing Loan (NPL) secara bersama-sama mempunyai pengaruh yang signifikan terhadap intermediasi Bank Perkreditan Rakyat (BPR) di wilayah Eks-Karesidenan Banyumas. Variabel deposito dan PDRB secara parsial berpengaruh signifikan terhadap intermediasi Bank Perkreditan Rakyat (BPR).

B. Saran

1. Bank Perkreditan Rakyat (BPR) di wilayah Eks-Karesidenan Banyumas harus tetap menjaga Loan to Deposit Ratio (LDR) agar tidak mengalami penurunan maupun peningkatan nilai Loan to Deposit Ratio (LDR) agar tingkat likuiditas perbankan tetap terjaga. Bank Perkreditan Rakyat (BPR) juga perlu berhati hati dalam pemberian kredit, pemberian kredit yang tidak diawasi akan berdampak buruk bagi perekonomian daerah, karena setiap pemberian kredit mempunyai resiko, resiko yang sering terjadi ialah ketidak mampuan nasabah dalam mengembalikan kredit atau kredit macet;

2. Agar Loan to Deposit Ratio (LDR) tidak melebihi batas aman, BPR perlu mengontrol besarnya nilai LDR. Loan to Deposit Ratio (LDR) berhubungan terbalik dengan deposito, maka BPR perlu meningkatkan simpanan deposito agar nilai LDR tidak terlalu tinggi dan tidak melebihi batas aman, dengan cara meningkatkan promosi produk-produknya kepada masyarakat melalui berbagai media, khususnya produk deposito agar masyarakat mengetahui dengan jelas segala ketentuan yang berkaitan dengan simpanan deposito. Meskipun PDRB berpengaruh positif dengan peningkatan LDR, namun BPR harus tetap berhati-hati dalam mengeluarkan kredit kepada masyarakat agar kredit yang tersalurkan tidak terlalu besar yang mengakibatkan meningkatnya Loan to Deposit Ratio (LDR).

\section{DAFTAR PUSTAKA}

Bank Indonesia. Berbagai Edisi. Direktori Perbankan Indonesia. Bank Indonesia. Jakarta.

Bank Indonesia Purwokerto. 2013. Statistik Ekonomi dan Keuangan Daerah bulan September. 2013. Purwokerto.

Gujarati, damodar. 2012. Ekonometrika dasar. Erlangga. Jakarta.

Harmanta dan Ekananda. 2005. "Disintermediasi Fungsi Perbankan di Indonesia Pasca Krisis 1997: Faktor Permintaan dan Penawarandi Indonesia, Sebuah Pendekatan dengan Model Disequilibrium, Buletin Ekonomi Moneter dan Perbankan". Edisi Juni 2005.

Kasmir. 1999. Bank dan Lembaga Keuangan lainnya. PT grafindo persada. Jakarta.

Nachrowi, Nachrowi D dan Hardius Usman. Pendekatan Populer dan Praktis Ekonometrika Untuk Analisis Ekonomi dan Keuangan. 2006. Lembaga Penerbit Fakultas Ekonomi Universitas Indonbesia. Jakarta. 
Purwaningtyas, M.Y Satyawati. 2011. Faktor-Faktor yang Mempengaruhi Intermediasi Perbankan di Indonesia Periode 2001:I-2009.1V. Skripsi. Fakultas Ekonomi Universitas Jenderal Soedirman. Purwokerto. (Tidak dipublikasikan)

Simorangkir, O. P, Drs .1986. Dasar-Dasar dan Mekanisme Perbankan. Aksara Persada Indonesia, Jakarta.

Sudarman, Vina Oktaviani. 2009. Estimasi Time Lag RSBI terhadap Suku Bunga Kredit serta Pengaruh Suka Bunga Kredit, PDB, dan NPL terhadp Intermediasi Perbankan Periode 2001:I sampai dengan 2008:III. Skripsi. Fakultas Ekonomi Universitas Jenderal Soedirman. Purwokerto. (Tidak dipublikasikan).

Undang-Undang RI No. 10 tahun 1998, Tentang Perbankan, Sekretariat Kabinet RI, Jakarta, 1998. 